\title{
PENGARUH KUALITAS LAYANAN LOGISTIK, KEPUASAN PELANGGAN, DAN CITRA MEREK TERHADAP LOYALITAS PELANGGAN JASA LOGISTIK MENGGUNAKAN STRUCTURAL EQUATION MODEL
}

\author{
Citra Ayu Wardhani ${ }^{1)}$, Anita Sugianto ${ }^{2)}$, Budi Hermana ${ }^{3)}$ \\ ${ }^{1,2)}$ Program Studi Teknik Industri, Fakultas Teknologi Industri, Universitas Gunadarma \\ ${ }^{3}$ Program Studi Magister Manajemen, Fakultas Ekonomi, Universitas Gunadarma \\ e-mail: wardhanicitraayu@gmail.com ${ }^{1}$, anita_sugianto@staff.gunadarma.ac.id ${ }^{2}$, \\ bhermana@staff.gunadarma.ac.id ${ }^{3}$
}

\begin{abstract}
ABSTRAK
Kualitas layanan logistik, kepuasan pelanggan, dan citra merek merupakan variabel yang digunakan untuk mengetahui pengaruhnya terhadap loyalitas pelanggan. Keempat variabel itu terbentuk dari 24 indikator dan 5 dimensi yang ada. Selain itu, penelitian ini juga dilakukan untuk mengetahui nilai CSI perusahaan. Penelitian dilakukan terhadap pelanggan dari perusahaan logistik di Indonesia dengan menggunakan metode SEM (Structural Equation Model) dan juga metode CSI (Customer Satisfaction Index). Sehingga diperoleh hipotesis bahwa tiga variabel tersebut memiliki hubungan yang signifikan atau berpengaruh terhadap loyalitas pelanggan, dengan nilai CR sebesar -1,996 dan P sebesar 0,046 untuk kualitas kayanan logistik. Sementara untuk kepuasan pelanggan memiliki nilai CR sebesar 2,550 dan P sebesar 0,012 terhadap loyalitas pelanggan, serta untuk citra merek memiliki nilai CR sebesar 9,534 dan nilai P sebesar *** terhadap loyalitas pelanggan. Selain itu, tingkat kepuasan pelanggan terhadap perusahaan masuk dalam kategori puas karena memiliki nilai CSI sebesar $78,806 \%$.
\end{abstract}

Kata kunci: Kualitas layanan logistik, Loyalitas, Structural Equation Model, Customer Satisfaction Index.

\begin{abstract}
Logistics Servqual, customer satisfaction, and brand image are variables that used to determaine the effect on customer loyalty. Four variables are formed from 24 indicators and 5 dimensions. In addition, this study was also tp determine the CSI value of the company. This study was conducted on customer from logistics companies using SEM (Structural Equation Model) method and CSI (Customer Satisfaction Index) method. The hypothesis is obtained that three variables have significant relationship with customer loyalty, in the manner of CR value is -1,996 and $P$ value is 0,046 for logistics servqual. While for customer satisfaction has CR value is 2,550 and $P$ value is 0,012 on customer loyalty, and for brand image has CR value is 9,534 and $P$ value is $* * *$ on customer loyalty. In addition, the level of customer satisfaction with companies is satisfactory because it has 78,806\% of CSI value.
\end{abstract}

Keywords: Logistic servqual, Loyalty, Structural Equation Model, Customer Satisfaction Index.

\section{PENDAHULUAN}

Kualitas layanan logistik yang baik dapat meningkatkan daya saing keuntungan karena dapat berpengaruh terhadap loyalitas pelanggan. Sistem logistik dikatakan baik apabila dalam memenuhi kepuasan pelanggan dapat melakukan kinerja perusahaan dengan waktu yang tepat dan juga harga yang dapat bersaing [1]. Sementara kualitas layanan merupakan suatu hal yang harus diunggulkan dalam memenuhi kebutuhan pelanggan [2]. Kualitas layanan logistik dalam hal ini yaitu bagaimana perusahaan bidang jasa melakukan pelayanan terbaik dari sisi logistik, misalnya yaitu informasi tentang progres waktu terhadap pengiriman barang sehingga para pengguna jasa tersebut bisa melacak dengan mekanisme e-map. Selain itu, ketepatan waktu dalam distribusinya atau dari sisi logistiknya, serta keamanan barang yang dikirim dan diterima oleh pengguna dari jasa tersebut. Kepuasan pelanggan akan timbul dengan sendirinya apabila pelayanan yang dirasakan melebihi harapan yang diinginkan. Pelanggan akan merasa puas dengan kinerja yang diberikan perusahaan apabila telah memenuhi harapannya [3]. Adanya kepuasan 
maupun kekecewaan pelanggan akan membuat perusahaan jasa atau produk terus meningkatkan layanan kualitasnya. Suara dari pelanggan ini, yang akan terus dijadikan bahan evaluasi suatu perusahaan. Citra merek dari suatu perusahaan biasanya timbul dari persepsi pengguna, dan persepsi dari seorang pengguna dapat mempengaruhi pengguna lainnya. Citra merek dinyatakan sebagai kesan serta keyakinan pelanggan terhadap perusahaan atau suatu merek [4]. Penilaian citra merek yang dikatakan baik tidak hanya dilihat dari sistem logistik yang diterapkan oleh perusahaan jasa pengiriman barang, tetapi juga dilihat dari karyawan dan kurirnya dalam hal melayani pengguna jasanya. Loyalitas pelanggan bukan dinilai dari jumlah konsumen yang membelinya satu kali, tetapi pada jumlah konsumen yang menjadi pembeli tetap. Loyalitas merupakan aktivitas pembelian yang terjadi dalam kurun waktu tertentu dengan kuantitas tidak kurang dari dua kali [5]. Loyalitas biasanya timbul jika pengguna jasa tersebut sudah merasa puas terhadap pelayanan yang diberikan, baik dari sisi pendistribusian maupun citra merek dari perusahaan jasa tersebut.

J\&T atau JNT merupakan perusahaan layanan pengiriman barang. Perusahaan ini merupakan perusahaan yang baru diresmikan bulan Agustus 2015 di kantor pusatnya yaitu Pluit, Jakarta Utara. Meskipun J\&T/JNT tergolong perusahaan jasa pengiriman baru, namun sudah memiliki gerai drop point di banyak lokasi di Indonesia. Bahkan di kota besar sendiri pun, bisa di setiap kelurahan ataupun kecamatan sudah ada gerai drop point $\mathrm{J} \& \mathrm{~T} / \mathrm{JNT}$.

Berdasarkan penjelasan di atas, maka penulis ingin mengetahui pengaruh dari kualitas layanan logistik, kepuasan pelanggan, dan citra merek terhadap loyalitas pelanggan pada jasa pengiriman J\&T/JNT. Penelitian ini juga ingin mengetahui nilai CSI perusahaan. Hal tersebut didasari oleh cepat berkembangnya perusahaan J\&T/JNT dalam bersaing dengan kompetitornya yang sudah berdiri sejak lama. Selain itu, di beberapa $e$ commerce juga telah tersedia jasa pengiriman dengan menggunakan J\&T/JNT.

\section{Kualitas layanan logistik}

Kualitas layanan logistik merupakan elemen penting dalam pemasaran untuk menciptakan kepuasan terhadap pelanggan, khususnya dalam industri jasa [6]. Pelayanan yang diberikan kepada pelanggan sudah menjadi ukuran dasar dalam persaingan logistik. Telah banyak definisi yang menjabarkan bagaimana kualitas layanan logistik dapat memuaskan pelanggan [7]. Apabila logistik dari suatu perusahaan unggul, maka dapat menciptakan perusahaan menjadi bersaing dengan kompetitornya. Hal yang dapat dilakukan yaitu dengan koordinasi antara ahli logistik dengan departemen pemasaran [8].

\section{Kepuasan Pelanggan}

Menurut penelitian yang dilakukan Fornell, dkk menyimpulkan bahwa kepuasan pelanggan terjadi saat harapan dari pelanggan telah terpenuhi maka keluhan dari pelanggan akan berkurang dan secara tidak langsung akan meningkatkan kepuasan pelanggan [9]. Semantara menurut Stopka, dkk bahwa kepuasan pelanggan merupakan hal yang sangat penting bagi perusahaan khususnya dalam bidang logistik agar perusahaan tersebut dapat bersaing dengan kompetitornya [10]. Apabila perusahaan tidak memenuhi harapan dari perusahaan maka pelanggan akan beralih ke perusahaan sejenis lainnya. Kepuasan pelanggan berbeda dengan loyalitas pelanggan, karena kepuasan pelanggan untuk mengukur seberapa besar harapan pelanggan yang dipenuhi oleh perusahaaan sementara loyalitas pelanggan untuk mengukur peluang atau kemungkinan pelanggan dalam melakukan aktivitas pembelian kembali dan segala aktivitas yang berkaitan dengan perusahaan $[11,12]$. 


\section{Citra Merek}

Menurut Yoo, dkk citra merek di definisikan sebagai persepsi pelanggan yang dibuat berdasarkan ingatan mereka terhadap perusahaan. Citra merek merupakan hal yang penting dalam memberikan informasi mengenai perusahaan dari sisi kinerjanya, selain itu menghubungan merek perusahaan tersebut ke dalam memori pelanggan [13]. Zeithaml, dkk mengungkapkan bahwa citra merek dapat mempengaruhi pelanggan mengenai persepsinya kepada perusahaan maupun produk dan layanannya [14]. Mazanec menyimpulkan bahwa citra merek sangat berhubungan dengan kepuasan pelanggan dan juga mempengaruhi loyalitas pelanggan tersebut [15].

\section{Loyalitas Pelanggan}

Loyalitas pelanggan merupakan aktivitas berulang yang dilakukan pelanggan dalam membeli produk ataupun menggunakan layanan tertentu. Loyalitas dari pelanggan merupakan hal yang dibutuhkan perusahaan, karena biaya yang dibutuhkan untuk menarik pelanggan baru adalah enam kali lebih tinggi dibandingkan dengan mempertahankan pelanggan yang lama [16]. Oleh sebab itu, pelanggan yang loyal merupakan aset perusahaan. Namun, mempertahankan pelanggan yang ada dan membuatnya menjadi pelanggan yang loyal bukan permasalahan yang mudah. Dasar awal dalam menilai pelanggan yang loyal yaitu dilihat dari seberapa banyak terjadinya pengulangan pembelian produk maupun layanan jasa dari perusahaan [17]. Menurut Kuehn, pengukuran terhadap pelanggan yang loyal yaitu dengan peluang atau kemungkinan pelanggan dalam pembelian kembali produk [18]. Sementara menurut Hari, definisi pelanggan yang loyal tidak hanya dilihat berdasarkan aktivitas pembelian secara berulang, karena hal tersebut tidak dapat membedakan pelanggan dengan loyalitas asli maupun palsu [19]. Pelanggan yang loyal fokus terhadap aspek ekonomi, transaksi, dan memperhatikan hubungannya dengan perusahaan. Markey dan Hopton menungkankan bahwa pelanggan yang loyal memiliki tingkat fleksibel harga yang lebih rendah, bahkan pelanggan tersebur rela membayar premi agar dapat berhubungan dengan perusahaan bersangkutan. Namun, pelanggan yang kurang loyal hanya fokus pada aspek ekonomi. [20]. Beberapa penelitian menyimpulkan bahwa pelanggan yang loyal cenderung memberikan informasi positif dari mulut ke mulut. $[21,22]$.

\section{METODE PENELITIAN}

Objek yang digunakan dalam penelitian ini adalah PT Globat Jet Express atau yang dikenal dengan J\&T/JNT. Sementara subjek pada penelitian ini (responden) adalah pengguna jasa J\&T/JNT di wilayah Jabodetabek sebanyak 300 responden yang dilakukan pada April hingga Juni 2019. Pengumpulan data dengan memanfaatkan google form yang dapat menyebar kuesioner secara online. Selain itu, penelitian ini menggunakan bantuan perangkat lunak (software) IBM SPSS Statistics 24 dan AMOS Graphics. Metodologi yang digunakan pada penelitian ini dijabarkan dalam alur (flowchart) yang telah dibuat. Berikut merupakan alur (flowchart) metodologi penelitian yang dapat dilihat pada Gambar 1. 
Pengaruh Kualitas Layanan Logistik, Kepuasan Pelanggan, dan Citra Merek Terhadap Loyalitas Pelanggan Jasa Logistik Menggunakan Structural Equation Model

\section{Citra Ayu Wardhani, Anita Sugianto, Budi Hermana}

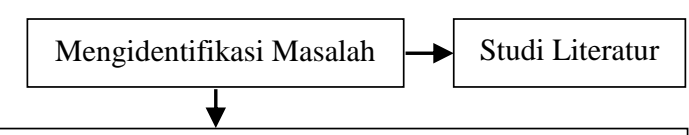

Menentukan Tujuan Penelitian:

1. Menganalisa pengaruh kualitas layanan logistik, kepuasan pelanggan, dan citra merek terhadap loyalitas pelanggan pada jasa pengiriman menggunakan metode SEM (Structural Equation Model).

2. Mengetahui nilai CSI perusahaan.

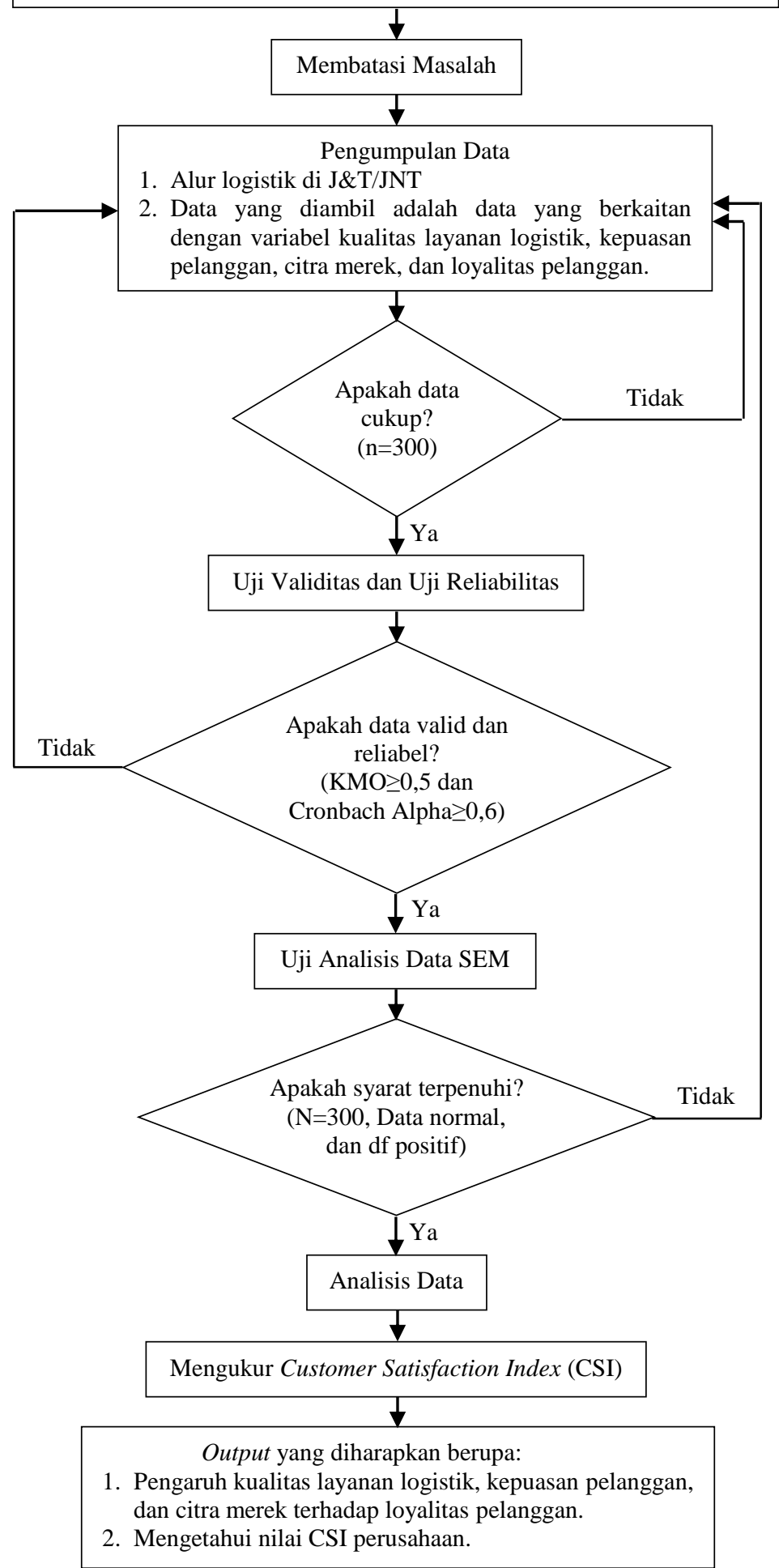

Gambar 1. Flowchart Metodologi Penelitian 
Penelitian ini menggunakan beberapa jurnal yang dijadikan referensi dalam pengambilan data, dalam bentuk kuesioner. Berikut merupakan beberapa sumber penelitian yang mejadi dasar pengambilan data dijabarkan dalam Tabel 1.

Tabel 1. Studi Literatur

\begin{tabular}{|c|c|c|c|}
\hline No & Penulis (Tahun) & Judul Penelitian & Kesimpulan \\
\hline 1 & $\begin{array}{l}\text { Fernandes, Daniel } \\
\text { Winter, Moori, Roberto } \\
\text { Giro, and Filho, Valdir } \\
\text { Antonio Vitoriono } \\
\text { (2018) }\end{array}$ & $\begin{array}{l}\text { Logistic service quality as } \\
\text { a mediator between logistic } \\
\text { capabilities and customer } \\
\text { satisfaction. }\end{array}$ & $\begin{array}{l}\text { Penelitian ini membuktikan bahwa kapabilitas logistik } \\
\text { memiliki dampak langsung terhadap kepuasan pelanggan } \\
\text { dan berhubungan positif dengan kualitas layanan logistik. } \\
\text { Selain itu, kualitas layanan logistik juga memiliki } \\
\text { hubungan yang positif dengan kepuasan pelanggan [23]. }\end{array}$ \\
\hline 2 & $\begin{array}{l}\text { Huang, Yu-kai, Kuo, Yi- } \\
\text { wei, and Xu, Shi-wei } \\
\text { (2009) }\end{array}$ & $\begin{array}{l}\text { Applying importance } \\
\text { performance analysis to } \\
\text { evaluate logistic service } \\
\text { quality for online shopping } \\
\text { among retailing delivery }\end{array}$ & $\begin{array}{l}\text { Penelitian ini menyimpulkan bahwa terdapat hubungan } \\
\text { yang positif antara kualitas layanan logistik dengan } \\
\text { kepuasan dan loyalitas pelanggan. Kesimpulan lainnya } \\
\text { yaitu antara kepuasan pelanggan dengan loyalitas } \\
\text { pelanggan terdapat hubungan yang positif [24]. }\end{array}$ \\
\hline 3 & $\begin{array}{l}\text { Cetin, Dilek, Kuscu, Asli, } \\
\text { Ozcam, Dilek Saglik, } \\
\text { Erdem, Yusuf Can } \\
\text { (2016) }\end{array}$ & $\begin{array}{l}\text { Brand image, satisfaction, } \\
\text { and brand loyalty - how } \\
\text { effect are they in } \\
\text { automative industry market } \\
\text { share }\end{array}$ & $\begin{array}{l}\text { Kesimpulan pada penelitian ini yaitu terdapat hubungan } \\
\text { langsung antara citra merek dengan kepuasan pelanggan, } \\
\text { begitupun dengan loyalitas pelanggan. Selain itu, antara } \\
\text { kepuasan pelanggan dengan loyalitas pelanggan terdapat } \\
\text { hubungan langsung dan terdapat hubungan langsung juga } \\
\text { antara loyalitas pelanggan dengan saham [25]. }\end{array}$ \\
\hline
\end{tabular}

Berdasarkan jurnal referensi yang digunakan, maka penelitian ini menggunakan tiga hipotesis. Hipotesis yang akan diuji pada penelitian ini menggunakan metode SEM. Berikut ini merupakan penjabaran dari ketiga hipotesis yang telah dibuat.

1. Kualitas layanan logistik memiliki hubungan signifikan dengan loyalitas pelanggan

Penelitian sebelumnya telah menjelaskan bahwa hubungan antara kualitas layanan logistik dengan loyalitas pelanggan terdapat hubungan yang postiif. Hal tersebut terbukti bahwa pelanggan yang mendapat pelayanan yang baik dan puas terhadap pelayanan yang diberikan akan semakin loyal terhadap pemberi layanan itu. Sehingga sifat persisnya antar kepuasan pelanggan dengan loyalitas merupakan masalah yang empiris [24]. Berdasarkan jurnal Huang, dkk juga dapat disimpulkan bahwa kualitas layanan logistik memiliki hubungan yang positif dengan loyalitas pelanggan. Indikator yang digunakan dalam kualitas layanan logistik yaitu dengan menerapkan lima konsep. Lima konsep yang dimaksud adalah kualitas informasi, prosedur logistiknya, ketetapan, keamanan, dan prosedur dalam ketidaksesuaian logistik [24]. Berdasarkan pemaparan yang telah dijabarkan, maka dapat dibuat hipotesis bahwa kualitas layanan logistik memiliki hubungan signifikan dengan loyalitas pelanggan.

2. Kepuasan pelanggan memiliki hubungan signifikan dengan loyalitas pelanggan

Menurut jurnal referensi dari peneliti Huang, dkk menyebutkan bahwa terdapat hubungan positif antara kepuasan pelanggan dengan loyalitas pelanggan, hal tersebut terbukti dari penelitian yang dilakukannya pada e-commerce (perdagangan elektronik) di Taiwan [24]. Jurnal tersebut dibuat juga berdasarkan pada penelitian sebelumnya bahwa hubungan antara kedua variabel tersebut merupakan masalah yang empiris. Sehingga dapat diperoleh hipotesis bahwa terdapat hubungan yang signifikan antara kepuasan pelanggan dengan loyalitas pelanggan.

3. Citra merek memiliki hubungan signifikan dengan loyalitas pelanggan

Salah satu jurnal referensi yang digunakan dalam penelitian ini yaitu penelitian dari Cetin, dkk dipaparkan beberapa penelitian yang membahas hubungan antara citra merek dengan loyalitas pelanggan [25]. Menurut Mazanec dijelaskan bahwa citra merek tidak hanya berpengaruh terhadap kepuasan pelanggan tetapi juga mempengaruhi dari sisi loyalitas [15]. Sehingga dapat diperolah hipotesis bahwa citra merek memiliki hubungan signifikan dengan loyalitas pelanggan. 
Pengaruh Kualitas Layanan Logistik, Kepuasan Pelanggan, dan Citra Merek Terhadap Loyalitas Pelanggan Jasa Logistik Menggunakan Structural Equation Model

Citra Ayu Wardhani, Anita Sugianto, Budi Hermana

\section{HASIL DAN PEMBAHASAN}

Hasil dan analisa pada penelitian ini dibagi menjadi beberapa bagian yaitu profil responden, measuremnet model, structural model, dan perhitungan CSI.

\section{Profil Responden}

Responden pada penelitian ini sebanyak 300 orang dengan kriterianya yaitu pengguna jasa JNT/J\&T dan berdomisili di Jabodetabek, yang dapat dilihat pada Tabel 2. Responden pada penelitian ini berusia rata-rata 22,01 tahun atau 22 tahun, dengan usia termuda 17 tahun dan usia tertua 54 tahun.

Tabel 2. Profil Responden

\begin{tabular}{cclcc}
\hline No & Karakteristik & \multicolumn{1}{c}{ Jenis } & Frekuensi & Persentase \\
\hline 1 & Pendidikan & SMA/SMK & 82 & $27,33 \%$ \\
& & Diploma & 35 & $11,67 \%$ \\
& & Sarjana & 174 & $58,00 \%$ \\
& & Lainnya & 9 & $3,00 \%$ \\
2 & \multirow{2}{*}{ Jenis Kelamin } & Pria & 50 & $16,67 \%$ \\
& & Wanita & 250 & $83,33 \%$ \\
3 & Rata-Rata & 1 Kali & 104 & $34,67 \%$ \\
& Menggunakan JNT & 2-3 Kali & 150 & $50,00 \%$ \\
& dalam 1 Bulan & 4-5 Kali & 31 & $10,33 \%$ \\
& & $>6$ Kali & 15 & $5,00 \%$ \\
\hline
\end{tabular}

\section{Measurement Model}

Measurement model atau analisis faktor konfirmatori (CFA) merupakan analisis faktor yang digunakan untuk menguji model pengukuran (measurement model). Menurut Maruyama 1998 CFA tidak dimaksudkan untuk menghasilkan model, melainkan menguji model pengukuran yang dikembangkan atas dasar kajian teori tertentu [26]. Analisis faktor konfirmatori digunakan untuk pengujian validitas dan reliabilitas dengan melihat nilai loading factor, KMO, cronbachs alpha, AVE dan CR yang dapat dilihat pada Tabel 3.

Tabel 3. Analisis Faktor Konfirmatori (CFA)

\begin{tabular}{|c|c|c|c|c|c|c|c|c|c|}
\hline No & Variabel & Kode & Mean & $\begin{array}{c}\text { Standard } \\
\text { Deviation }\end{array}$ & $\begin{array}{c}\text { Loading } \\
\text { Factor }\end{array}$ & KMO & $\begin{array}{l}\text { Cron- } \\
\text { bach } \alpha\end{array}$ & AVE & $\mathbf{C R}$ \\
\hline \multirow[t]{11}{*}{1} & Kualitas Layanan Logistik & LSQ1 & 3,96 & 0,786 & 0,744 & 0,903 & 0,883 & 0,475 & 0,907 \\
\hline & & LSQ2 & 4,07 & 0,837 & 0,787 & & $0,888^{*}$ & $0,500^{*}$ & $0,908 *$ \\
\hline & & LSQ3 & 3,65 & 0,940 & 0,600 & & & & \\
\hline & & LSQ4 & 3,61 & 0,817 & 0,582 & & & & \\
\hline & & LSQ5 & 3,74 & 0,841 & 0,680 & & & & \\
\hline & & LSQ6 & 3,83 & 0,959 & 0,769 & & & & \\
\hline & & LSQ7 & 4,15 & 0,795 & 0,644 & & & & \\
\hline & & LSQ8 & 3,78 & 1,081 & $0,481 *$ & & & & \\
\hline & & LSQ9 & 4,28 & 0,855 & 0,769 & & & & \\
\hline & & LSQ10 & 3,70 & 0,923 & 0,723 & & & & \\
\hline & & LSQ11 & 3,77 & 0,849 & 0,737 & & & & \\
\hline \multirow[t]{7}{*}{2} & Kepuasan Pelanggan & $\mathrm{CS} 1$ & 4,10 & 0,885 & 0,850 & 0,892 & 0,889 & 0,604 & 0,914 \\
\hline & & $\mathrm{CS} 2$ & 4,37 & 0,717 & 0,802 & & & & \\
\hline & & $\mathrm{CS} 3$ & 3,92 & 0,898 & 0,723 & & & & \\
\hline & & CS4 & 4,21 & 0,812 & 0,798 & & & & \\
\hline & & CS5 & 4,01 & 0,866 & 0,779 & & & & \\
\hline & & CS6 & 4,47 & 0,715 & 0,664 & & & & \\
\hline & & CS7 & 4,04 & 0,910 & 0,808 & & & & \\
\hline \multirow[t]{3}{*}{3} & Citra Merek & BI1 & 3,94 & 0,782 & 0,794 & 0,686 & 0,789 & 0,704 & 0,877 \\
\hline & & $\mathrm{BI} 2$ & 3,88 & 0,802 & 0,874 & & & & \\
\hline & & $\mathrm{BI} 3$ & 4,03 & 0,811 & 0,847 & & & & \\
\hline \multirow[t]{3}{*}{4} & Loyalitas Pelanggan & CL1 & 3,65 & 0,911 & 0,904 & 0,744 & 0,897 & 0,829 & 0,936 \\
\hline & & CL2 & 3,66 & 0,891 & 0,900 & & & & \\
\hline & & CL3 & 3,72 & 0,920 & 0,927 & & & & \\
\hline
\end{tabular}


Berdasarkan Tabel 3, Analisis Faktor Konfirmatori menunjukkan nilai mean, standard deviation, loading factor, KMO, Cronbach Alpha, AVE, dan CR. Nilai mean menunjukkan nilai rata-rata jawaban responden dari setiap indikator, sementara nilai standard deviation menunjukkan standar deviasi yang artinya sebaran data pada penelitian ini. Berdasarkan tabel di atas tidak ada standard deviation yang bernilai 0 , artinya yaitu jawaban dari responden pada penelitian ini bervariasi. Loading factor menunjukkan koefisien bobot faktor yang diperoleh dari output IBM SPSS Statistics 24. Menurut Hair, dkk penelitian dianggap layak apabila nilai loading factor (koefisien bobot faktor) dari setiap indikatornya tidak kurang dari 0,5 [27]. Berdasarkan tabel di atas, terdapat satu indikator yang memiliki nilai di bawah 0,5 , yaitu pada indikator LSQ8 yang memiliki nilai loading factor sebesar 0,481. Dikarenakan hal tersebut, maka indikator LSQ8 dinyatakan tidak valid, karena nilai loading factor menunjukkan pengujian validitas secara konvergen. Selain itu, pada bagian struktural model akan dihilangkan indikator LSQ8 karena tidak valid.

Pengujian validitas tidak hanya dilihat dari nilai loading factor, karena pengujian validitas bisa dilihat dari nilai KMO and Bartlett's Test of Sphericity (Kaiser-Mayer-Okin) dan juga nilai AVE (Average Variance Extracted). nilai KMO and Bartlett's Test of Sphericity (Kaiser-Mayer-Okin) digunakan untuk mengukur kecukupan sampling. Menurut Arikunto apabila nilai KMO lebih besar dari 0,5, maka akan dinyatakan valid [28]. Berdasarkan tabel di atas, keempat variabel laten dinyatakan valid karena memiliki nilai di atas 0,5. Semenatara, nilai AVE (Average Variance Extracted) digunakan untuk melihat rata-rata varians antar indikator dalam suatu variabel laten. Menurut Hair, dkk dan menurut Chin dalam Jogiyanto dan Willy, variabel laten dinyatakan valid jika memiliki nilai AVE $\geq 0,5[27,29,30]$. Berdasarkan tabel di atas, hanya satu variabel laten yang tidak valid karena bernilai 0,475 yaitu kualitas layanan logistik. Hal tersebut terjadi karena terdapat satu indikator dari kualitas layanan logistik yang mempunyai nilai loading factor di bawah 0,5, yaitu LSQ8. Tetapi apabila dilakukan perhitungan kembali nilai AVE dengan menghilangkan indikator LSQ8, hasilnya yaitu 0,5. Sehingga dapat disimpulkan bahwa keempat variabel laten yang digunakan valid.

Pengujian reliabilitas dilakukan dengan dua cara yaitu melihat nilai Cronbach Alpha dan CR (Composite Reliability). Menurut Arikunto apabila koefisien Alpha Cronbach bernilai 0,6 atau lebih, maka dapat dinyakatan andal [31]. Berdasarkan tabel di atas, keempat variabel laten dinyaatakan andal atau reliabel karena memiliki nilai Alpha Cronbach di atas 0,6. Sedangkan, CR (Composite Reliability) yang digunakan untuk menguji keandalan dan konsistensi data. Menurut Hair, dkk variabel laten dikatakan reliabel jika memiliki nilai $\geq 0,7$ [27]. Berdasarkan tabel di atas, keempat variabel laten yang digunakan reliabel atau andal karena memiliki nilai CR di atas 0,7.

\section{Structural Model}

Tahap structural model dilakukan untuk memastikan bahwa model yang dibuat sesuai dengan data dan untuk mengetahui ada atau tidaknya pengaruh antar variabel laten. Pengujian tehadap structural model pada penelitian ini menggunakan estimasi model maximum likelihood, yaitu menggunakan sampel penelitian antara 200 hingga 500 sampel. Berikut merupakan structural model pada penelitian ini. 


\section{Citra Ayu Wardhani, Anita Sugianto, Budi Hermana}

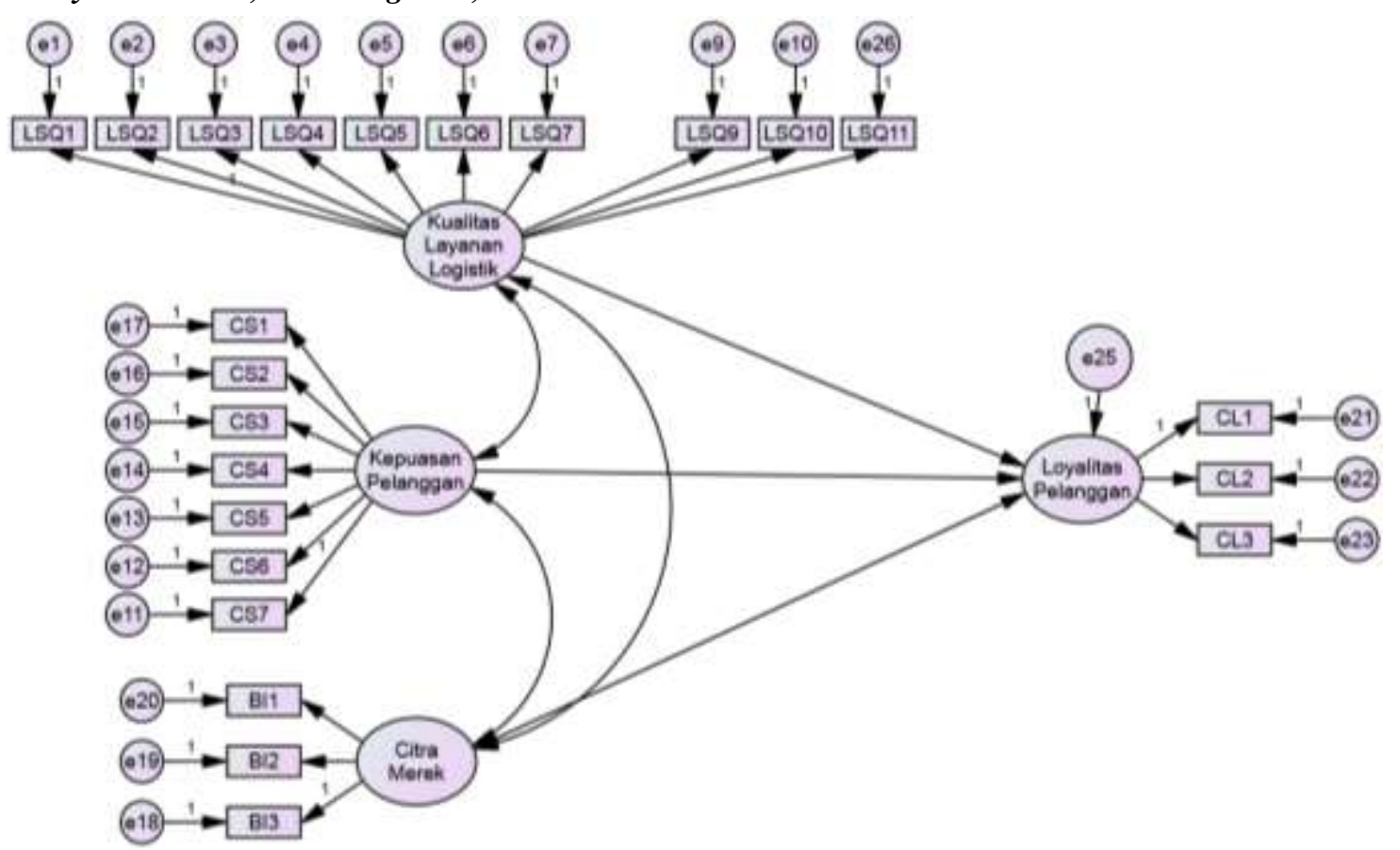

Gambar 2. Model Struktural

Berdasarkan Gambar 2 pada model struktural, penghilangan pada indikator LSQ8 dikarenakan indikator tersebut tidak valid. Apabila sudah dihilangkan seperti pada model di atas, langkah selanjutnya yaitu melakukan evaluasi kriteria GOF (Goodness Of Fit). Tahap tersebut dilakukan untuk pengujian terhadap kesesuaian model dengan beberapa kriteria yang telah ditentukan. Berikut merupakan hasil GOF pada penelitian ini.

Tabel 4. Evaluasi Kriteria GOF

\begin{tabular}{ccccc}
\hline No & Goodness of Fit index & Cut off value & Output AMOS & Keterangan \\
\hline 1 & Chi-square & Diharapkan kecil & 582,047 & \\
2 & Signifikasi & $\geq 0,05$ & 0,000 & Poor fit \\
3 & RMSEA & $\leq 0,08$ & 0,073 & Good fit \\
4 & GFI & $\geq 0,90$ & 0,850 & Marginal fit \\
5 & AGFI & $\geq 0,90$ & 0,815 & Marginal fit \\
6 & CMIN/DF & $\leq 2,00$ & 2,598 & Poor fit \\
7 & TLI & $\geq 0,90$ & 0,897 & Marginal fit \\
8 & CFI & $\geq 0,94$ & 0,909 & Marginal fit \\
\hline
\end{tabular}

Berdasarkan Tabel 4, dapat dilihat mengenai evaluasi terhadap kriteria GOF hanya ada 1 index yang termasuk dalam kategori good fit, karena memenuhi nilai cut off value [32,33]. Sehingga dengan hasil tersebut tidak dapat melakukan uji hipotesis karena model struktural penelitian ini tidak fit dengan data yang diperoleh. Selain itu, juga pada tabel di atas juga diketahui bahwa beberapa kriteria masih dikategorikan marginal fit. Oleh sebab itu, dibutuhkan modifikasi agar bisa membuat beberapa index dikategorikan dalam good fit dan dapat menguji hipotesis. Berikut merupakan hasil modifikasi yang dilakukan pada penelitian ini. 


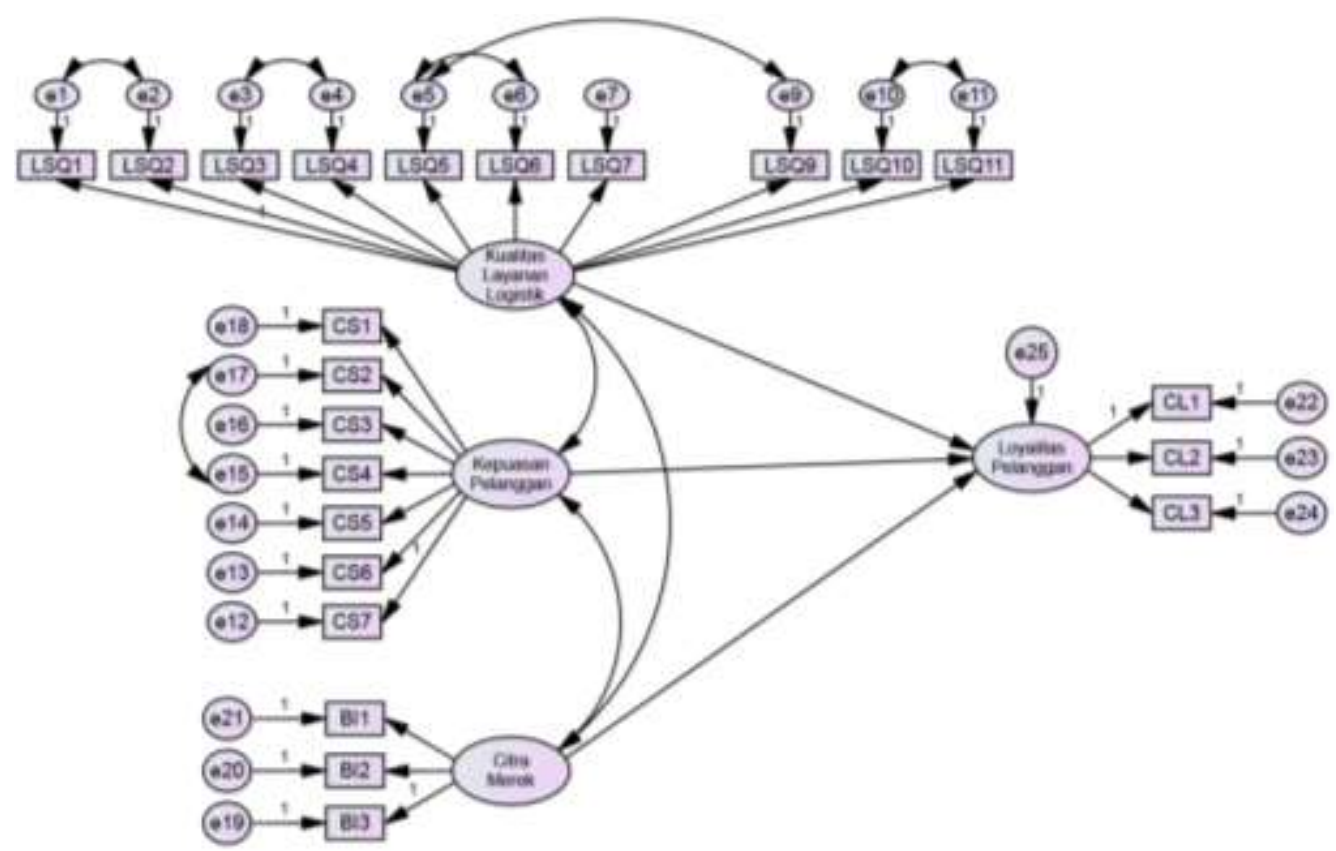

Gambar 3. Model Struktural Akhir

Berdasarkan Gambar 3, terjadi enam kali modifikasi yang dilakukan pada penelitian ini. Modifikasi model pada penelitian ini dilakukan atas dasar pendapat peneliti Arbuckle yang melakukan modifikasi model pada AMOS dengan melihat modification indices [34]. Hal yang dilakukan untuk memodifikasi yaitu dengan memberikan garis koneksi antara error. Setiap pemberian garis koneksi atau melakukan modifikasi, output dari AMOS pasti akan mengalami perubahan. Sehingga tabel modification indices juga akan berbeda-beda. Menurut Rozeboom (1966) dijelaskan bahwa korelasi antara error (unique factor covariance) akan selalu ada saat beberapa pernyataan disampaikan dalam satu waktu (waktu yang sama), yaitu kesalahan pada satu item pernyataan akan berpengaruh positif terhadap kesalahan pada item pernyataan yang lain [35]. Pemberian korelasi antar error akan terus dilakukan hingga model dinyatakan fit. Setelah dinyatakan fit, maka dapat dilakukan evaluasi kriteria GOF (Goodness Of Fit). Berikut merupakan evaluasi keriteria GOF setelah melakukan modifikasi.

Tabel 5. Evaluasi Kriteria GOF Akhir

\begin{tabular}{ccccc}
\hline No & Goodness of Fit index & Cut off value & Output AMOS & Keterangan \\
\hline 1 & Chi-square & Diharapkan kecil & 432,020 & \\
2 & Signifikasi & $\geq 0,05$ & 0,000 & Poor fit \\
3 & RMSEA & $\leq 0,08$ & 0,057 & Good fit \\
4 & GFI & $\geq 0,90$ & 0,889 & Marginal fit \\
5 & AGFI & $\geq 0,90$ & 0,859 & Marginal fit \\
6 & CMIN/DF & $\leq 2,00$ & 1,982 & Good fit \\
7 & TLI & $\geq 0,90$ & 0,937 & Good fit \\
8 & CFI & $\geq 0,94$ & 0,945 & Good fit \\
\hline
\end{tabular}

Berdasarkan Tabel 5, dapat dilihat bahwa pada penelitian ini model sudah dikatakan fit karena terdapat 4 indikator yang termasuk dalam kategori good fit, 2 indikator yang termasuk dalam kategori marginal fit, 1 indikator yang termasuk dalam kategori poor fit, dan nilai chi-square yang lebih kecil dari sebelumnya. Sehingga dapat disimpulkan bahwa model telah fit dengan data karena mayoritas indikator pada penelitian ini tergolong dalam 
Pengaruh Kualitas Layanan Logistik, Kepuasan Pelanggan, dan Citra Merek Terhadap Loyalitas Pelanggan Jasa Logistik Menggunakan Structural Equation Model

Citra Ayu Wardhani, Anita Sugianto, Budi Hermana

good fit. Maka dari itu, dapat dilakukan uji hipotesis. Berikut merupakan rincian uji hipotesis pada penelitian ini.

Tabel 6. Uji Hipotesis

\begin{tabular}{cllccc}
\hline No & \multicolumn{2}{c}{ Variabel } & CR & P & Keterangan \\
\hline 1 & Loyalitas Pelanggan & Kualitas Layanan Logistik & $-1,996$ & 0,046 & Diterima \\
2 & Loyalitas Pelanggan & Kepuasan Pelanggan & 2,500 & 0,012 & Diterima \\
3 & Loyalitas Pelanggan & Citra Merek & 9,534 & $* * *$ & Diterima \\
\hline
\end{tabular}

Berdasarkan Tabel 6 dapat dilihat uji hipotesis yang diperoleh dari output software AMOS Grpahics. Hipotesis akan diterima jika nilai CR (Critical Ratio) memiliki nilai di atas 1,96 dan memiliki nilai P (Probabilitas) di bawah 0,05 [36]. CR (Critical Ratio) atau rasio kritis merupakan rasio deviasi tertentu dari nilai rata-rata standard deviasi, atau nilai t-hitung. Besar nilai CR >1,96 jika dengan signifikansi <0,05. Sehingga, dapat diketahui bahwa ketiga hipotesis pada penelitian ini diterima karena memiliki nilai CR di atas 1,96 dan nilai $\mathrm{P}$ di bawah 0,05 . Hipotesis pertama pada penelitian ini jika dilihat dari tabel di atas adalah kualitas layanan logistik memiliki hubungan signifikan yang negatif dengan loyalitas pelanggan. Sementara arti dari hipotesis yang kedua yaitu antara kepuasan pelanggan dengan loyalitas pelanggan memiliki hubungan signifikan yang positif. Sedangkan pada hipotesis yang ketiga memiliki arti bahwa antara citra merek dengan loyalitas pelanggan memiliki hubungan positif yang sangat signifikan. Dikatakan sangat signifikan karena memiliki nilai $\mathrm{P}$ sebesar $(* * *)$,yaitu memiliki tingkat signifikansi di bawah 0,01 yang artinya sangat sangat signifikan.

\section{Perhitungan CSI}

Tingkat kepuasan pelanggan terhadap keseluruhan indikator pada penelitian ini menggunakan indeks kepuasan pelanggan (CSI), yang hasil perhitungannya untuk PT Global Jet Express dapat dilihat pada Tabel 7.

Tabel 7. Perhitungan CSI

\begin{tabular}{cllllll}
\hline Kode & Dimensi & MIS & MSS & WF & WS & CSI \\
\hline LSQ1 & Reliability & 4,41 & 3,96 & 0,041 & 0,162 & 78,806 \\
LSQ2 & Reliability & 4,44 & 4,07 & 0,041 & 0,167 & \\
LSQ3 & Reliability & 4,49 & 3,65 & 0,042 & 0,152 & \\
LSQ4 & Tangible & 4,52 & 3,61 & 0,042 & 0,151 & \\
LSQ5 & Reliability & 4,47 & 3,74 & 0,041 & 0,155 & \\
LSQ6 & Reliability & 4,47 & 3,83 & 0,041 & 0,159 & \\
LSQ7 & Reliability & 4,53 & 4,15 & 0,042 & 0,174 & \\
LSQ8 & Reliability & 4,41 & 3,78 & 0,041 & 0,154 & \\
LSQ9 & Reliability & 4,53 & 4,28 & 0,042 & 0,180 & \\
LSQ10 & Tangible & 4,51 & 3,7 & 0,042 & 0,155 & \\
LSQ11 & Responsive & 4,5 & 3,77 & 0,042 & 0,157 & \\
CS1 & Tangible & 4,52 & 4,10 & 0,042 & 0,172 & \\
CS2 & Tangible & 4,56 & 4,37 & 0,042 & 0,185 & \\
CS3 & Emphaty & 4,52 & 3,92 & 0,042 & 0,164 & \\
CS4 & Reliability & 4,52 & 4,21 & 0,042 & 0,176 & \\
CS5 & Reliability & 4,52 & 4,01 & 0,042 & 0,168 & \\
CS6 & Reliability & 4,64 & 4,47 & 0,043 & 0,192 & \\
CS7 & Tangible & 4,47 & 4,04 & 0,041 & 0,167 & \\
BI1 & Assurance & 4,45 & 3,94 & 0,041 & 0,162 & \\
BI2 & Tangible & 4,47 & 3,88 & 0,041 & 0,161 & \\
BI3 & Tangible & 4,44 & 4,03 & 0,041 & 0,166 & \\
CL1 & Emphaty & 4,54 & 3,65 & 0,042 & 0,154 & \\
CL2 & Assurance & 4,47 & 3,66 & 0,041 & 0,152 & \\
CL3 & Emphaty & 4,51 & 3,72 & 0,042 & 0,155 & \\
\hline TOTAL & & 107,91 & 94,54 & & 3,940 & \\
\hline & & & & &
\end{tabular}


Kolom dimensi menunjukkan dimensi yang dibutuhkan dalam perhitungan CSI. Nilai MIS (Mean Importance Score) diperoleh dengan menghitung nilai rata-rata kepentingan atau harapan setiap indikator dengan jumlah responden. Nilai MIS untuk indikator LSQ1 yaitu sebesar 4,41. Total nilai MIS yaitu sebesar 107,91. Nilai MSS (Mean Satisfaction Score) diperoleh dengan menghitung nilai rata-rata persepsi setiap indikator dengan jumlah responden. Nilai MSS untuk indikator LSQ1 yaitu sebesar 3,96. Total nilai MSS yaitu sebesar 94,54. Nilai WF (Weight Factor) diperoleh dengan cara membagi membagi nilai MIS setiap indikator dengan total nilai MIS seluruh indikator. Nilai WF untuk indikator LSQ1 yaitu sebesar 0,041. Sehingga total nilai WF sebesar 1. Nilai WS (Weight Score) diperoleh dengan cara mengalikan setiap nilai WF dengan nilai MSS setiap indikator. Nilai WF untuk indikator LSQ1 yaitu sebesar 0,162. Total nilai WS yaitu sebesar 3,940. Nilai CSI (Customer Satisfaction Index) diperoleh dari membagi total nilai WS seluruh indikator dengan nilai HS (Highest Score) lalu dikalikan 100\%. Nilai HS merupakan skala terbesar yang digunakan pada penelitian ini yaitu 5. Berdasarkan perhitungan maka termasuk dalam kategori puas karena memiliki nilai CSI sebesar 78,806\% yang artinya pelanggan puas dengan PT Global Jet Express.

\section{KESIMPULAN}

Kesimpulan merupakan jawaban dari tujuan dari penelitian ini. Terdapat dua kesimpulan pada penelitian ini. Pertama adalah kualitas layanan logistik berpengaruh terhadap loyalitas pelanggan kerena memiliki nilai CR sebesar -1,996 dan P sebesar 0,046, kepuasan pelanggan berpengaruh terhadap loyalitas pelanggan kerena memiliki nilai CR sebesar 2,550 dan $\mathrm{P}$ sebesar 0,012, dan citra merek berpengaruh terhadap loyalitas pelanggan karena memiliki nilai CR sebesar 9,534 dan P sebesar ***. Kedua yaitu tingkat kepuasan pelanggan terhadap perusahaan memuaskan karena memiliki nilai CSI sebesar $78,806 \%$.

\section{DAFTAR PUSTAKA}

[1] Hayati, Enty Nur. 2015. Supply Chain Management (SCM) dan Logistic Management. Semarang: Universitas Stikubang.

[2] Tjiptono, Fandy. 2005. Pemasaran Jasa Edisi Pertama. Yogyakarta: Bayumedia Publishing.

[3] Kotler, Philip dan Gary Amstrong. 2001. Dasar-dasar Pemasaran. Edisi Bahasa Indonesia. Jakarta: PT Prenhallindo.

[4] Kotler, Philip. 1999. Manajemen Pemasaran. Jilid II. Edisi Milenium. Jakarta: PT. Prenhallindo.

[5] Griffin, Jill. 2005. Customer Loyalty: Menumbuhkan \& Mempertahankan Kesetiaan Pelanggan. Jakarta: Erlangga.

[6] Mentzer, T. M. and Williams, L. R., 2001. The role of logistics leverage in marketing Strategy. Journal of Marketing Channels, Vol. 8, No. 3, pp. 29-47.

[7] Hess, M., 2002. Shipping news: The implications of electronic commerce for logistics and freight transport. Resources Conservation \& Recycling, Vol. 36, No. 3, pp. 211240.

[8] Fornell, C., 1992. A national customer satisfaction barometer: The Swedish Experience. Journal of Marketing, Vol. 56, No.1, pp.6-21.

[9] Fornell, C., Johnson, M.D., Anderson, E.W., Cha, J. and Bryant, B.E. 1996. The American customer satisfaction index: nature, purpose, and findings. Journal of Marketing, Vol. 60 No. 4, pp. 7-18.

[10] Stopka, O., Cerná, L. and Zitricky, V. 2016. Methodology for measuring the customer satisfaction with the logistics services. Nase More, Vol. 63 No. 3, pp. 189-194. 
Pengaruh Kualitas Layanan Logistik, Kepuasan Pelanggan, dan Citra Merek Terhadap Loyalitas Pelanggan Jasa Logistik Menggunakan Structural Equation Model

Citra Ayu Wardhani, Anita Sugianto, Budi Hermana

[11] Anne, W. M., 2003. Share of wallet in retailing: The effects of consumer satisfaction, loyalty cards and shopper characteristics. Journal of Retailing, Vol. 79, No. 2, pp. 97-106.

[12] Reichheld, F. R., Markey, J. and Hopton, C., 2000. E-commerce loyalty-applying the traditional rules of business for online success. European Business Journal, Vol. 12, No. 4, pp. 173-179.

[13] Yoo, B., Donthu, N. \& Lee, S. 2000. An examination of selected marketing mix elements and brand equity. Journal of the academy of marketing science. 28(2), 195-211.

[14] Zeithaml, V. A. , Bitner, M. J. \& Gremler, D. D. 1996. Services Marketing. McGraw Hill. New York.

[15] Mazanec. J. A. 1995. Positioning Analysis with Self-Organizing Maps An Exploratory Study on LuxuryHotels. Cornell Hotel and Restaurant Administration Quarterly, 36(6), 80-95.

[16] Rosenberg, L. J. and Czepiel, J. A., 1984. A marketing approach to customer retention. Journal of Consumer Marketing, Vol. 1, No. 2, pp. 45-51.

[17] Brown, G. H., 1952. Brand loyalty - fact or fiction. Advertising Age, Vol. 23, No. 1, pp.53-55.

[18] Kuehn, A., 1962. Consumer brand choice as a learning process. Journal of Advertising Research, Vol. 2, No. 4, pp. 10-17.

[19] Day, R. L., 1977. Extending the concept of consumer satisfaction. Advances in Consumer Research, Vol. 4, No. 1, pp. 149-154.

[20] Bendapudi, N. and Berry, L. L., 1997. Customers' motivations for maintaining relationships with service providers. Journal of Retailing, Vol. 73, No. 1, pp. 15-37.

[21] Oliva, T.A., Oliver, R. L. and MacMillian, I.C., 1992. A catastrophe model for developing service satisfaction strategies. Journal of Marketing, Vol. 56, No. 3, pp. 83-95.

[22] Rust, R. and Zahorik, A. J., 1993. Customer satisfaction, customer retention, and market share. Journal of Retailing, Vol. 69, No. 2, pp. 193-214.

[23] Fernandes, Daniel Winter, Moori, Roberto Giro, dan Filho, Valdir Antonio Vitoriono. 2018. Logistic Service Quality As A Mediator Between Logistic Capabilities and Customer Satisfaction. Brazil : Universitas Presbiteriana Mackenzie.

[24] Huang, Yu-kai, Kuo, Yi-Wei, dan Xu, Shi-Wei. 2009. Applying ImportancePerformance Analysis To Evaluate Logistic Service Quality For Online Shopping Among Retailing Delivery. Taiwan : Universitas Nanhua.

[25] Cetin, Dilek, Kuscu, Asli Ozcam, Dilek Saglik, dan Erdem, Yusuf Can. 2016. Brand Image, Satisfaction, and Brand Loyalty - How Effective Are They in the Automotive Industry Market Share. Turki. Universitas Bogazici dan Yeditepe.

[26] Maruyama, G. M. 1998. Basic of Structural Equation Modeling. Thousand Oaks: Sage Publications.

[27] Hair, dkk. 2010. Multuvariate Data Analysis Seventh Edition. New Jersey: Pearson Prentice Hall.

[28] Arikunto, Suharsimi. 2006. Metode Penelitian Kualitatif. Jakarta: Bumi Aksara.

[29] Chin, W and Todd P. 1995. On the Use, Usefulness, and Ease of Use of Structural Equation Modeling in MIS Research: A Note of Caution. Journal of Management Information System Quartely. Vol 9 No. 5.

[30] Jogiyanto dan Abdillah, Willy. 2009. Konsep \& Aplikasi PLS (Partial Least Square) untuk Penelitian Empiris. Eds Pertama. Yogyakarta: BPFE Yogyakarta.

[31] Arikunto, Suharsimi. 2002. Metodologi Penelitian. Jakarta: PT Rineka Cipta.

[32] Ferdinand, A, 2000. Structural Equation Modelling dalam Penelitian Manajemen. Semarang: Penerbit Universitas Diponegoro. 
[33] Wijanto, Setyo Hari. 2008. Structural Equation Modeling dengan LISREL 8.8. Yogyakarta: Graha Ilmu.

[34] Arbuckle, W.S. 2000. Ice Cream Third Edition. Avi Publishing Company. Inc West Port, Connecticut.

[35] Rozeboom, W. W. 1988. Factor indeterminacy: the saga continues. British Journal of Mathematical and Statistical Psychology, 41, 209-226.

[36] Ghozali, Imam. 2007. Aplikasi Analisis Multivariate dengan Program SPSS. Semarang: Universitas Diponegoro. 